\title{
Konsepsi Bangunan Keluarga Sakinah Bagi Pasangan Suami Istri Yang Telah Bercerai Pada Masyarakat Muslim di Kota Manado
}

\author{
Ardianto (ardiantotola76@gmail.com) \\ Institut Agama Islam Negeri Manado, Sulawesi Utara, Indonesia \\ Ridwan Jamal (ridwanjamalstain@gmail.com) \\ Institut Agama Islam Negeri Manado, Sulawesi Utara, Indonesia \\ Munir Tubagus (matrix.bagus@gmail.com) \\ Institut Agama Islam Negeri Manado, Sulawesi Utara, Indonesia
}

\begin{abstract}
This study aims to describe the perception of married couples who have divorced to building harmonious family. The analysis is directed at the opinion of the informant research on the basic concept of harmonic family building which is understood to be glue of building harmonious family. This reserach is a case study using the qualitative approach. The results showed that couples who have been in Muslim Community in Manado city perceive that responsibility and mutual understanding, balance, and honesty is the foundation of harmonic family building.
\end{abstract}

Keywords: Conception, Harmony Family, Divorce.

\begin{abstract}
ABSTRAK
Penelitian ini bertujuan mendeskripsikan persepsi pasangan suami istri yang telah bercerai terhadap bangunan keluarga sakinah. Analisis diarahkan pada pendapat para informan penelitian tentang konsepsi dasar bangunan keluarga sakinah yang dipahami yang dapat menjadi perekat bangunan keluarga sakinah. Penelitian merupakan jenis studi kasus dengan menggunakan pendekatan kualitatif. Hasil penelitian menunjukkan bahwa pasangan suami istri yang telah pada masyarakat muslim di kota Manado mempersepsi bahwa tangungjawab dan saling pengertian, keseimbangan, dan kejujuran merupakan fondasi bangunan keluarga sakinah.
\end{abstract}

Kata Kunci: Konsepsi, Keluarga Sakinah, Perceraian. 


\section{PENDAHULUAN}

Keluarga adalah suatu lembaga yang dibangun melalui proses perkawinan antara dua manusia yang berlainan jenis. Menurut Undang-undang Perkawinan No. 1 tahun 1974, tujuan perkawinan adalah dimaksudkan untuk membangun keluarga yang bahagia. Dalam undangundang tersebut, secara tegas disebutkan bahwa "Perkawinan adalah ikatan lahir batin antara seorang pria dengan seorang wanita sebagai suami istri dengan tujuan membentuk keluarga (rumah tangga) yang bahagia berdasarkan Ketuhanan Yang Maha Esa”.

Keluarga yang bahagia sebagaimana dinyatakan dalam UU di atas dalam peristilahan Islam disebut sebagai keluarga sakinah, yaitu keluarga yang dibangun atas dasar cinta dan kasih sayang di antara anggota keluarga dengan berpegang teguh pada aturan-aturan agama. Itulah sebabnya, Islam memandang bahwa salah satu tujuan pernikahan adalah untuk menciptakan sakinah antara suami, istri, dan anak-anaknya. Hal ini ditegaskan dengan jelas dalam alQuran Surat Ar-Rum (21), yang terjemahannya ialah:

"Dan di antara tanda-tanda (kebesaran)-Nya ialah Dia menciptakan pasanganpasangan untukmu dari jenismu sendiri, agar kamu cenderung dan merasa tenteram kepadanya, dan Dia menjadikan di antaramu rasa kasih dan sayang. Sungguh, pada yang demikian itu benar-benar terdapat tanda-tanda (kebesaran Allah) bagi kaum yang berpikir" (QS. Ar-Rum: 21).

Adanya sakinah/ketenteraman, merupakan modal yang paling berharga dalam membina rumah tangga bahagia. Dengan adanya rumah tangga yang bahagia, jiwa dan pikiran menjadi tenteram, tubuh dan hati mereka menjadi tenang, kehidupan dan penghidupan menjadi mantap, kegairahan hidup akan timbul, dan ketentraman bagi laki-laki dan perempuan secara menyeluruh akan tercapai (Departemen Agama, 2009: 481).

Di samping sakinah, al-Quran menyebut dua kata lain dalam konteks kehidupan rumah tangga, yaitu mawaddah dan rahmah. Dalam al-Quran dan Tafsirnya, Departemen Agama menerjemahkan mawaddah dan rahmah dengan 'rasa kasih dan sayang'. Dalam penjelasan kosa katanya, mawaddah berasal dari fi'il wadda-yawaddu, waddan wa mawaddatan yang artinya cinta, kasih, dan suka. Sedangkan, rahmah berasal dari fi'il 
rahima-yarhamu-rahmatan wa marhamatan yang berarti sayang, menaruh kasihan (Departemen Agama, 2009:478).

Agar perkawinan yang sakinah dapat diwujudkan, maka menurut Al-Khasyt (1999) dibutuhkan bangunan etika dan tata krama berkeluarga, yaitu:

a. Mu'asyarah bi al-ma'ruf yaitu hubungan yang baik antara suami istri sebagaimana diisyaratkan Al Qur'an dalam surat An Nisa': 19. Kehidupan suami istri diliputi oleh saling toleransi, tukar menukar, dan rasa kebersamaan.

b. Menanamkan keadilan dalam kehidupan keluarga. Kebersamaan dalam keadilan di antara keluarga membawa kepada ketentraman rohani yang menjadi kebutuhan masingmasing anggota keluarga. Masing-masing menyikapi perbedaan tersebut secara adil di antara mereka, ada pembagian tugas di antara anggota keluarga sesuai dengan kekuatan, kemampuan, kegemaran dan kesukaan masing-masing, baik yang muda maupun yang tua.

c. Adanya rasa kasih sayang dan penghormatan kepada setiap anggota keluarga. Yang tua menyayangi yang muda dan yang muda menghormati yang tua. Rasulullah SAW bersabda: "Bukan termasuk golongan kami orang yang tidak menyayangi yang muda dan tidak menghormati yang tua".

d. Menghargai kemampuan masing-masing. Secara psikologis sikap ini akan membangun rasa kebersamaan dan ketentraman dalam keluarga karena masing-masing anggota keluarga dapat menghargai kemampuan yang satu dan yang lain.

e. Menyimpan rahasia keluarga. Dalam peristilahan Al-Qur'an suami istri diibaratkan sebagai pakaian (libas). "Hunna liba:sun lakum wa antum liba:sun lahunna" (Suami menjadi pakaian istri dan istri menjadi pakaian suami).

Dalam Keputusan Direktur Jenderal Bimbingan Masyarakat Islam dan Urusan Haji Nomor D/7/1999 tentang Petunjuk Pelaksanaan Pembinaan Gerakan Keluarga Sakinah Bab III Pasal 3 dikemukakan bahwa keluarga sakinah adalah keluarga yang dibina atas perkawinan yang sah, mampu memenuhi hajat hidup spiritual dan material secara layak dan seimbang, diliputi suasana kasih sayang antara anggota keluarga dan lingkungannya dengan 
selaras, serasi, serta mampu mengamalkan, menghayati dan memperdalam nilai-nilai keimanan, ketakwaan, dan akhlak mulia.

Namun demikian, konsepsi bangunan keluarga sakinah bagi sebaian kecil pasangan suami istri yang telah diikat oleh suatu ikrar suci melalui proses pernikahan itu tampkanya belum dimaknai secara mendalam. Faktanya kasus perceraian masih merupakan trend (kecenderungan) yang sangat menyita perhatian publik. Hal ini bisa dilihat dari seringnya masalah tersebut menjadi berita hangat di media massa, baik lokal maupun nasional. Tampaknya masalah ini bukan hanya terjadi pada keluarga dari kelas tertentu, namun juga menimpa keluarga dari semua lapisan/kelas sosial. Data Pengadilan Tinggi Agama Manado yang dirilis oleh Manado Post (25 Maret 2013), misalnya, bahwa rata-rata setiap dua hari terjadi kasus perceraian. Selama kurun waktu dua tahun 2009 dan 2010 terjadi 472 kasus perceraian.

Pada tahun 2012, misalnya, sebanyak 245 perkara yang diperoses di Pengadilan Agama Manado dan 238 merupakan perkara gugatan cerai. Sedangkan, sisanya adalah perkara harta bersama, kewarisan, pembatalan perkawinan, dan pengesahan nikah. Dari 238 perkara gugatan cerai tersebut, sebanyak 69 kasus cerai talaq dan 169 cerai gugat. Pada tahun 2013 periode Januari sampai Oktober, data Pengadilan Agama Manado menunjukkan sebanyak 255 berkas perkara gugatan dan sebanyak 12 perkara merupakan permohonan (penetapan ahli waris, itsbat/wali nikah, dispensasi kawin, dan pengangkatan anak). Dari 255 perkara gugatan, sebanyak 243 merupakan perkara gugatan cerai yang terdiri atas 167 cerai gugat dan 76 cerai talak (Data Pengadilan Agama Manado, 2013).

Berdasarkan data di atas tampak bahwa angka perceraian pasangan suami istri pada masyakarat muslim khsususnya di Kota Manado meningkat dari tahun ke tahun. Ironisnya, kasus perceraian yang terjadi karena inisiatif pihak istri (gugat cerai) jumlahnya lebih besar daripada perceraian karena inisiatif pihak suami (talak). Hal ini tentunya memerlukan langkah-langkah strategis, sistematis, dan integratif untuk mengantisipasi kecenderungan negatif tersebut. Oleh karena itu, diperlukan penelitian yang mendalam untuk dijadikan rujukan-rujukan dalam melakukan tindakan pencegahan kasus perceraian. 
Fenomena meningkatnya kasus perceraian pada mayarakat muslim di Kota Manado sebagaimana dipaparkan di atas berbading lurus dengan data perceraian di Pengadilan Negeri Manado yang mencatat bahwa sebanyak 479 kasus (data tahun 2010-2011). Bahkan kecenderungan naiknya jumlah kasus perceraian ternyata tidak berubah sampai dengan tahun 2013. Artinya, kasus perceraian terjadi pada semua segmen kemasyarakatan. Dan, hal ini mestinya menjadi perhatian pemerintah terutama berkaitan dengan penyiapan infrastruktur kebijakan yang dapat menjadi pijakan normatif dalam penanganan masalah perceraian.

Kondisi yang terjadi di Kota Manado tidak menutup kemungkinan terjadi di daerahdaerah lain di Sulawesi Utara bahkan Indonesia pada umumnya. Di wilayah Kotamobagu, misalnya, Pengadilan Agama Kotamobagu mencatat pada tahun 2010 sebanyak 540 kasus perceraian. Angka ini terus meningkat dari tahun ke tahun. Pada tahun 2011 tercatat 644 kasus perceraian, tahun 2012 sebanyak 750, dan lebih memprihatinkan lagi, data pada Januari-Februari 2013 saja sudah tercatat sebanyak 200 kasus perceraian yang sedang diproses (Manado Post, 23 Maret 2013).

Berdasarkan pada data-data di atas tampak bahwa kasus perceraian pada masyarakat muslim di Sulawesi Utara menjadi trend negatif dan angkanya terus meningkat dari tahun ke tahun. Data yang terkonfirmasi pada Pengadilan Tinggi Agama Sulawesi Utara pada tahun 2011, misalnya, terdapat sebanyak 1090 perkara yang terdiri dari 271 perkara cerai talak, 772 cerai gugat, dan 47 perkara lain. Kenyataan ini tentu sangat memprihatinkan, sebab bagaimanapun, terjadinya perceraian itu menunjukkan bahwa pasangan suami-istri yang telah mengikat janji membangun keluarga sakinah, telah gagal mencapai cita-cita yang mereka dambakan ketika mengawali membangun rumah tangga yang sakinah.

Penelitian ini bertujuan mengkaji persepsi pasangan suami istri yang telah bercerai terhadap bangunan keluarga sakinah. Analisis diarahkan pada pendapat para informan penelitian tentang konsepsi dasar bangunan keluarga sakinah yang dipahami yang dapat menjadi perekat bangunan keluarga sakinah. 


\section{METODE PENELITIAN}

Penelitian merupakan jenis studi kasus dengan menggunakan pendekatan kualitatif. Rancangan studi kasus dapat digunakan untuk pengembangan teori yang diangkat dari sebuah latar penelitian (Bogdan dan Biklen, 1998). Rancangan ini diharapkan dapat menghasilkan teori dengan generalisasi lebih luas dan lebih umum terkait kasus perceraian.

Penelitian ini dilaksanakan di Kota Manado. Infroman penelitian ini adalah suami, istri sudah bercerai (10 Pasangan), anak-anak korban perceraian (5 orang), pegawai Pengadilan Agama Manado (3 orang), dan Ketua/Pegawai KUA di Kota Manado (3 orang). Teknik penjaringan informasi yang digunakan adalah teknik bola salju (snowball). Dalam penelitian kualitatif teknik untuk memperoleh data di lapangan dilakukan dengan tiga cara, yaitu: teknik wawancara terfokus, focus group dicussion (FGD), observasi, dan dokumentasi (Marshall, 1989). Dalam penelitian ini digunakan wawancara terfokus, observasi, dan dokumentasi.

Pengumpulan data dalam penelitian ini dilakukan secara bertahap. Pada tahap pertama peneliti melakukan penjajakan ke lokasi dalam rangka memperoleh gambaran secara umum tentang situs yang diteliti. Tahap berikutnya adalah melakukan eksplorasi, dimana dalam tahap ini peneliti mengumpulkan data secara lebih mendalam dan terarah dengan fokus penelitian, serta berusaha mencari sumber-sumber data atau informan yang kompeten dan memiliki pengetahuan, pemahaman, dan kepedulian yang tinggi terhadap pemasalahan yang sedang diteliti.

Dalam melakukan pengumpulan data, baik menggunakan teknik wawancara mendalam maupun dengan teknik observasi, digunakan alat bantu berupa buku catatan lapangan. Di samping itu apabila yang diwawancarai banyak maka digunakan alat perekam. Kedua alat tersebut digunakan untuk mencatat dan merekam jawaban-jawaban informan yang selanjutnya ditulis ulang ke dalam format transkrip wawancara dengan menyertakan koding yang terdiri dari tanggal, tempat, dan inisial informan. Sedangkan, untuk kegiatan observasi, selain format catatan lapangan juga digunakan alat dokumentasi yang berfungsi untuk mendokumentasikan perilaku-perilaku atau peristiwa-peristiwa penting yang muncul selama 
pelaksanaan observasi. Selanjutnya, dalam setiap melakukan observasi digunakan format catatan lapangan.

Data penelitian dianalisis selama pengumpulan data, yaitu analisis data selama pengumpulan data situs dilakukan dengan mengikuti proses yang dikemukakan oleh Bogdan dan Biklen (1998) dan Miles dan Huberman (1992), yaitu dimulai sejak atau bersamaan waktunya dengan proses pengumpulan data yang dilakukan secara bertingkat tiga atau empat kali tahapan pengumpulan data. Proses tersebut terdiri dari lima tahap analisis data yaitu: (1) penetapan fokus penelitian, (2) penyusunan temuan-temuan, (3) pembuatan rencana pengumpulan data berikutnya berdasarkan temuan-temuan dari pengumpulan data sebelumnya, (4) pengembangan pertanyaan analitik untuk mengumpulkan data berikutnya, (5) penetapan sasaran pengumpulan data berikutnya. Selama itu, peneliti berusaha menggali data dengan lebih terarah dengan melakukan wawancara ulang, apabila data yang diperoleh ternyata belum menyentuh pokok persoalan. Peneliti juga menuangkan hasil wawancara ke dalam transkrip yang telah disiapkan, dengan mengelompokkan data-data tersebut sesuai dengan tema-tema dalam fokus penelitian.

Peneliti merumuskan temuan penelitian dari data yang dianggap bersifat spesifik setelah melalui analisis etnografi. Dalam penelitian ini pengecekan keabsahan temuan dilakukan dengan tiga cara, yaitu: (1) kredibilitas, dilakukan dengan menggunakan teknik triangulasi baik triangulasi teknik data maupun triangulasi informan, (2) dependabilitas, dilakukan dengan meminta bantuan para ahli dan berbagai pihak yang memahami penelitian ini, dan (3) konfirmabilitas, dilakukan dengan cara melakukan pemeriksaan ulang terhadap data yang diperoleh dengan meminta konfirmasi lebih lanjut kepada para informan dan para ahli terkait, yakni ahli pendidikan, psikolog, ulama, dan hakim agama.

\section{HASIL PENELITIAN DAN PEMBAHASAN}

Temuan penelitian menunjukkan bahwa persepsi pasangan suami istri terhadap bangunan keluarga sakinah ialah adanya tanggung jawab dan mengerti keinginan 
isteri/suami, adanya keseimbangan (pendidikan, perkerjaan/ penghasilan, dan agama), dan adanya kejujuran.

Terkait dengan persepsi tentang adanya keseimbangan atau dalam bahasa agama sering disebut dengan se-kufu ini menjadi aspek yang penting dipersepsi oleh pasangan suami istri. Kufu adalah keseimbangan suami istri, baik dalam status sosial, kecantikan, pendidikan maupun agama. Hal ini merupakan unsur yang tidak boleh diabaikan dalam mewujudkan keluarga sakinah.

Gambaran tentang persepsi pasangan suami istri terhadap bangunan keluarga sakinah dapat dilihat dalam bagan berikut.

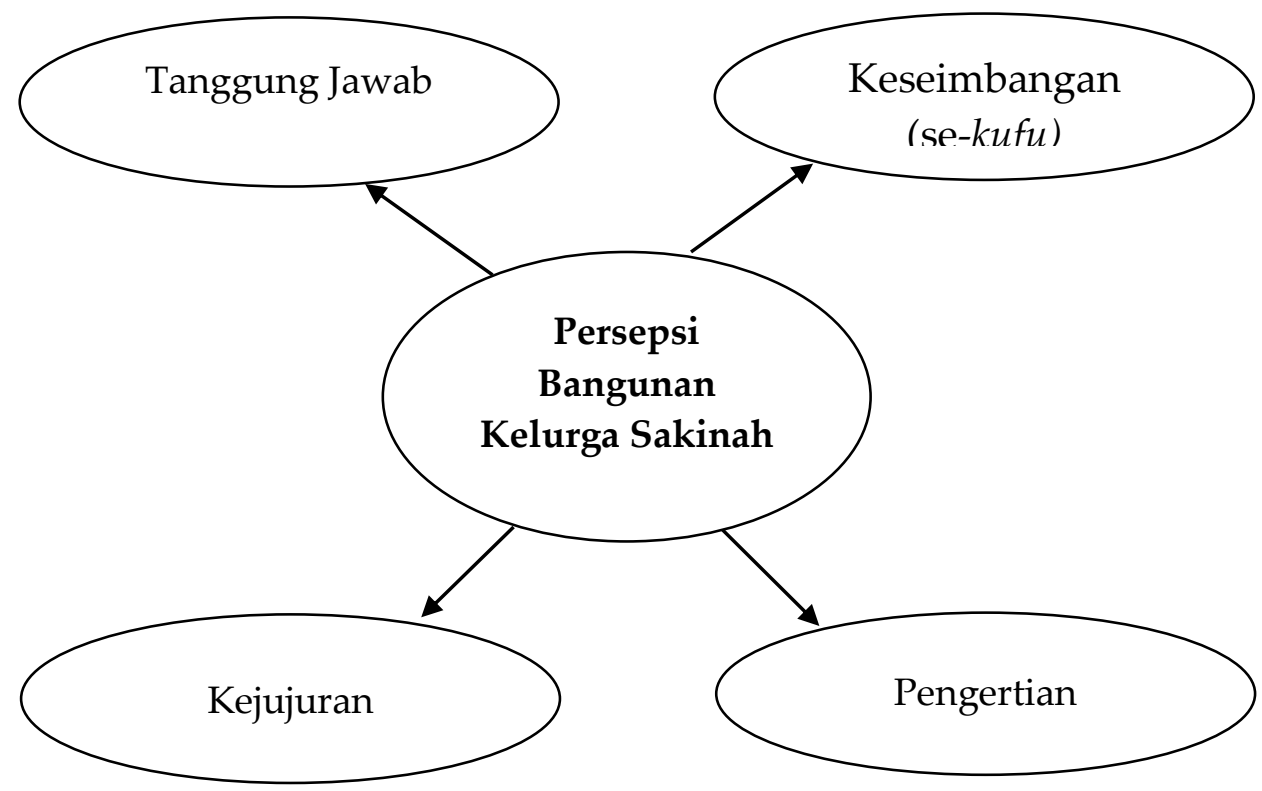

Gambar 1

Persepsi Pasangan Suami Istri terhadap

Bangunan Keluarga Sakinah

Al-Khasyt (1999) mengemukakan bahwa perkawinan yang sakinah akan dapat diwujudkan apabila keluarga itu dibangun berdasarkan etika dan tata krama berkeluarga. Etika dan tata krama berkeluarga itu antara lain dikemukakan oleh Al-Khasyt sebagai berikut:

a. Mu'asyarah bi al-ma'ruf yaitu hubungan yang baik antara suami istri sebagaimana diisyaratkan Al Qur'an dalam surat An Nisa': 19. Kehidupan suami istri diliputi oleh saling toleransi, tukar menukar, dan rasa kebersamaan. 
b. Menanamkan keadilan dalam kehidupan keluarga. Kebersamaan dalam keadilan di antara keluarga membawa kepada ketentraman rohani yang menjadi kebutuhan masingmasing anggota keluarga. Masing-masing menyikapi perbedaan tersebut secara adil di antara mereka, ada pembagian tugas di antara anggota keluarga sesuai dengan kekuatan, kemampuan, kegemaran dan kesukaan masing-masing, baik yang muda maupun yang tua.

c. Adanya rasa kasih sayang dan penghormatan kepada setiap anggota keluarga. Yang tua menyayangi yang muda dan yang muda menghormati yang tua. Rasulullah SAW bersabda: "Bukan termasuk golongan kami orang yang tidak menyayangi yang muda dan tidak menghormati yang tua".

d. Menghargai kemampuan masing-masing. Secara psikologis sikap ini akan membangun rasa kebersamaan dan ketentraman dalam keluarga karena masing-masing anggota keluarga dapat menghargai kemampuan yang satu dan yang lain.

e. Menyimpan rahasia keluarga. Dalam peristilahan Al-Qur'an suami istri diibaratkan sebagai pakaian (libas). "Hunna liba:sun lakum wa antum liba:sun lahunna" (Suami menjadi pakaian istri dan istri menjadi pakaian suami) (Al-Khasyt, 1999).

Berdasarkan temuan penelitian dan pendapat ahli di atas, setidaknya terdapat lima aspek dalam mewujudkan keluarga sakinah, pertama, mewujudkan kehidupan keberagamaan dalam keluarga dari segi keimanan. Kedua, peningkatan pengetahuan (ajaran) agama dan pengetahuan umum mengenai kehidupan keluarga yang harmonis. Ketiga, perhatian terhadap masalah kesehatan keluarga. Keempat, tercukupinya ekonomi keluarga. Terakhir, terciptanya hubungan sosial keluarga yang harmonis. Temuan penelitian menunjukkan bahwa persepsi pasangan suami istri terhadap bangunan keluarga sakinah ialah adanya tanggung jawab dan mengerti keinginan isteri/suami, adanya keseimbangan atau sekufu (pendidikan, perkerjaan/penghasilan, dan agama), dan adanya kejujuran.

Upaya mewujudkan keluarga sakinah yang harmonis, yaitu melalui (1) adanya saling pengertian, di antara suami istri hendaknya saling memahami dan mengerti tentang keadaan masing-masing, baik secara fisik maupun mental. Sebagai manusia, suami istri memil iki 
kelebihan dan kekurangan masing-masing. Tidak hanya berbeda jenis, tetapi juga berbeda sifat, sikap, tingkah laku dan pandangan hidup. Sebelumnya saling tidak mengenal dan bertemu setelah sama-sama dewasa; (2) saling menerima kenyataan, suami istri hendaknya sadar bahwa jodoh, rezeki, hidup dan mati itu di tangan Allah Swt. Tidak dapat dirumuskan secara matematis. Manusia hanya wajib ikhiar dan hasilnya merupakan suatu kenyataan yang harus diterima, termasuk keadaan suami atau istri masing-masing, harus diterima dengan tulus dan ikhlas; (3) saling melakukan penyesuaian diri, penyesuaian diri dalam keluarga berarti setiap anggota keluarga harus berusaha untuk saling mengisi kekurangan yang ada pada diri masing-masing serta mau menerima dan mengakui kelebihan yang ada pada orang lain di lingkungan keluarga. Kemampuan menyesuaikan diri oleh masing-masing anggota keluarga mempunyai dampak positif, baik bagi pembinaan keluarga maupun masyrakat dan bangsa; (4) memupuk rasa cinta, setiap pasangan suami istri menginginkan hidup bahagia. Kebahagiaan hidup adalah bersifat relatif sesuai dengan cita rasa dan keperluannya. Namun demikian, setiap orang berpendapat sama bahwa kebahagiaan adalah segala sesuatu yang dapat mendatangkan ketenteraman, keamanan, dan kedamaian serta segala sesuatu yang bersifat pemenuhan mental spiritual manusia. Untuk dapat mencapai kebahagiaan keluarga, hendaknya antara suami istri senantiasa berupaya memupuk rasa cinta dengan cara saling menyayangi, kasih mengasihi, hormat menghormati serta saling harga menghargai dan penuh keterbukaan; dan (5) melaksanakan azaz musyawarah, dalam kehidupan keluarga, sikap musyawarah, terutama antara suami isteri, erupakan sesuatu yang perlu diterapkan. Sesuai dengan prinsip bahwa tak ada suatu masalah yang tak dapat diselesaikan, selama prinsip musyawarah diamalkan. Dalam hal ini dituntut sikap terbuka, lapang dada, jujur, mau menerima dan memberi serta sikap tidak mau menang sendiri dari pihak istri ataupun suami. Sikap suka bermusyawarah dalam keluarga dapat menumbuhkan rasa memiliki dan rasa tanggung jawab di antara para anggota keluarga dalam menyelesaikan dan memecahkan masalah-masalah yang timbul. 
Prinsip-prinsip bangunan keluarga sakinah sebagaimana dikemukakan di atas, terepresentasi dalam konsep-konsep dasar keluarga sakinah yang dipersepsi oleh informan berdasarkan temuan penelitian ini.

\section{KESIMPULAN DAN SARAN}

Berdasarkan temuan penelitian dapat disimpulkan bahwa persepsi pasangan suami istri terhadap bangunan keluarga sakinah ialah adanya tanggung jawab dan mengerti keinginan isteri/suami, adanya keseimbangan (pendidikan, perkerjaan/penghasilan, dan agama), dan adanya kejujuran.

Berdasarkan kesimpulan penelitian di atas, proposisi ilmiah yang dapat dirumuskan dari penelitian yang dilalukan ini ialah pasangan suami istri yang bercerai itu mempersepsi bahwa tangung jawab dan saling pengertian, keseimbangan, dan kejujuran merupakan fondasi bangunan keluarga sakinah.

Sebagai implikasi yang dapat dikemukakan berdasarkan kesimpulan penelitian, maka beberapa saran dapat dikemukakan ialah (1) untuk para penyuluh agama, bimbingan kesejahteraan keluarga dalam bentuk paket dakwah Islam melalui bimbingan konseling Islam perlu diadakan secara intensif pada masyarakat guna memberikan pedoman, pendidikan, dan pemahaman tentang pentingnya menjalin keluarga yang harmonis. (2) untuk instansi terkait dan lembaga swadaya masyarakat (LSM) yang bergerak dalam bidang sosial, budaya, dan agama agar meningkatkan pelaksanaan Gerakan Keluarga Sakinah dengan penyusunan petunjuk teknis, sosialisasi program di masyarakat dan lintas program, orientasi, pendataan keluarga sakinah dan pelatihan pembinaan kelompok gerakan keluarga sakinah. Selain itu, bagi instansi terkait (khususnya Kantor Urusan Agama) perlu merevitalisasi eksistensi peran BP4 dengan meningkatkan kegiatan-kegiatan penasihatan perkawinan bagi para calon pengantin melalui kursus sesuai dengan standar modul yang ditetapkan, dan (3) untuk para peneliti disarankan agar melakukan penelitian sejenis dengan mengembangkan substansi masalah penelitian, yaitu persepsi terhadap 
bangunan keluarga sakinah perlu dianalisis pengaruhnya terhadap perceraian pasangan suami istri pada masyarakat muslim di Kota Manado melalui riset kuantitatif.

\section{UCAPAN TERIMA KASIH}

Artikel ini disusun berdasarkan hasil penelitian yang dilaksanakan pada tahun 2013 dengan dukungan anggaran DIPA STAIN Manado (saat ini IAIN Manado). Ucapan terima kasih disampaikan kepada Ketua STAIN Manado (saat ini Rektor IAIN Manado) dan Kepala P3M STAIN Manado (saat ini ketua LP2M IAIN Manado) yang telah memfasilitasi penelitian ini.

\section{DAFTAR PUSTAKA}

Al-Khasyt, Muhamad Usman. (1999). Sulitnya Berumah Tangga; Upaya Mengatasinya Menurut Qur'an Hadits dan Ilmu pengetahuan. Jakarta: GIP.

Al-Qur'an dan Terjemahannya. (1995). Mujamma' Al Malik Fahd Li Thinba'at Al Mushhhaf. Medinah: Munawwarah.

Anonim. (1985). Undang-Undang Perkawinan, UU No. 1 Tahun 1974, PP No. 9 tahun 1975. Surabaya: Pustaka Tinta Mas.

Anonim. (2000). Modul Pembinaan Keluarga Sakinah (Untuk Pelatihan Pembina Kelompok Sakinah). Jakarta: Direktorat Jenderal Bimas Islam dan Urusan Haji Proyek Peningkatan Kehidupan Keluarga Sakinah, Departemen Agama R.I.

Bogdan, R. C. dan Biklen, S. K. (1998). Qualitative Research In Education: An Introduction to Theory and Methods. Boston: Allyn and Bacon.

Departemen Agama, (2009). Al-Qur'an dan Tafsirnya. Jilid 7. (Edisi yang Disempurnakan). Jakarta: Departemen Agama RI.

Keputusan Direktur Jenderal Bimbingan Masyarakat Islam dan Urusan Haji Nomor D/7/1999 tentang Petunjuk Pelaksanaan Pembinaan Gerakan Keluarga Sakinah Bab III Pasal 3.

Manado Post . (2013). Data Pengadilan Tinggi Agama Manado. Manado Post Edisi 25 Maret 2013.

Manado Post. (2013). Perceraian di Manado Tinggi. Manado Post, Edisi 23 Maret 2013

Marshall, Catherine \& Rossman, Gretchen B. 1989. Designing Qualitative Research. 4th edition. Thousands Oaks: Sage Publication.

Miles, M. B. dan Huberman, A. M. (1992). Analisis Data Kualitatif. Terjemahan Tjetjep Rohidi. Jakarta: Universitas Indonesia Press.

Pengadilan Agama Manado. (2013). Laporan Tentang Perkara yang Diterima dan Diputus Pengadilan Agama Kota Manado. Dokumen Tidak Diterbitkan.

Zar, Sirajuddin. (2015). Konsep Keluarga Dalam Agama Islam, dalam, http://www.academia.edu.

\section{Sumber Online:}

http://suarakomunitas.net/baca/20861/awal-tahun--angka-perceraian-di-kota-manado-tinggi/ http://regional.kompas.com/read/2012/09/16/16111920/Perempuan.Manado.Kian.Sering.Gug at.Cerai 
Jurnal Ilmiah Al-Syir'ah Vol. 15 No. 1 Tahun 2017

Institut Agama Islam Negeri (IAIN Manado)

http://portalmanado.com/node/222

http://kotamanado.net/berita/read/683 